\title{
EVALUATION OF THE NOISE IMPACTS ON SLEEP QUALITY IN COMMUNITIES NEAR TO THE INTERNATIONAL AIRPORT EL DORADO IN COLOMBIA
}

\author{
MIGUEL DE LUQUE VILLA ${ }^{1,2}$, ANDRES CAMILO ACUÑA MENDEZ ${ }^{2,3}$, JUAN DIEGO VIRGUEZ2, \\ MARIAJOSE RUBIO ${ }^{2} \&$ CAMILA CANCHON TRIANA ${ }^{2,3}$ \\ ${ }^{1}$ Departamento de Ecología y Territorio, Facultad de Estudios Ambientales y Rurales, \\ Pontificia Universidad Javeriana, Colombia \\ ${ }^{2}$ Universidad de Cundinamarca, Facultad de Ciencias Agropecuarias, Colombia \\ ${ }^{3}$ SERUANS ENVIRONMENT SAS, Colombia
}

\begin{abstract}
The El Dorado International Airport is located in the city of Bogota and near the rural area in the city of Funza. This paper assesses the impact of environmental noise on the quality of life in communities as the result of airport activities. Environmental noise level measurements were carried at 62 monitoring points in the Fontibón District of Bogotá and Funza's rural area; the results were used to create noise maps using Arc-GIS 10.5 to reveal the spatial patterns of noise exposure. The Pittsburgh sleep quality index was adapted to Colombia (PSQI-CV) in order to identify sleep disturbances in the communities. The sound pressure levels were compared to the Colombia regulation threshold in Resolution 627/2006. The results showed that, during the daytime, $60 \%$ of the study area complied with this regulation, while at night-time, only $18 \%$ complied. The PSQI showed that $87 \%$ of the population surveyed in the study area had sleep disturbances. It was concluded that the airport noise mitigation strategies are not effective; thus, the coordination of development between El Dorado Airport and surrounding communities for land use planning is urgently needed in order to reduce noise exposure of the population. Keywords: noise impacts, Pittsburgh sleep quality index, airport noise, land use planning.
\end{abstract}

\section{INTRODUCTION}

Environmental noise can cause adverse health effects, and it is well documented that it can affect the well-being of people by interrupting basic activities such as sleep, rest, communication, concentration and cognition [1]. One of the main contributors to noise pollution in cities is airports [2].

The El Dorado International Airport is the main airport in Colombia, with great importance for the economic development of the country, depending on the number of passengers and cargo it moves. For several years, its entire transport system has used a large-scale operation as the central axis of transport activities, serving as an interchange and connection center for users of air transport at the domestic and international level [3]. Likewise, the development of the El Dorado Airport is reflected in its modernization, expansion of its infrastructure and projection of growth in air operations. Thus, its progress positively influences the creation of trade, development and employment for the population.

However, the high demand for passengers requires this airport to mobilize users and create a larger infrastructure complex, which is why the construction and expansion of the airport has been proposed through a project called: El Dorado II, which will be located between the municipalities of Madrid and Facatativá (Cundinamarca) and will serve 4.5 million passengers upon opening [4].

Planning tools plays an important role for the integration of the airport in the spatial, economic and social context of a city, which implies that they must provide valuable 
information for decision making and possible conflicts resolution of that may be generated, due to the presence of different interests and competences in the same territory. Land use planning is one of the most important actions local government can take to protect residents from adverse impacts caused by the airport, while keeping the airport in a healthy environment [5]. Adequate land-use planning around airports is of imperative importance because environmental impacts related to the airport operation can make the areas around the airport unsuitable for certain land uses [6].

This study evaluated the environmental noise in populations close to the airport activities of the El Dorado International Airport in order to understand the effect on health, specifically the quality of sleep of the population in the Fontibón District of Bogotá and Funza's rural area. The main objective of this study was to evaluate the impact of noise resulting from airport activities at the El Dorado International Airport on the communities in the Fontibón District of Bogotá and Funza's rural area and evaluate a possible solution from land use planning. This study was carried out by characterizing the distribution of environmental noise, evaluating the quality of sleep in the population, and evaluating the environmental impact of noise pollution in order to propose strategies to correct and mitigate the effects of noise on these communities.

\section{MATERIALS AND METHODS}

\subsection{Study area}

The study area included the Fontibón District, located in the northwestern part of Bogotá DC, where the El Dorado International Airport is located, and the Florida town in the rural area of Funza, which surrounds the airport runways (Fig. 1).

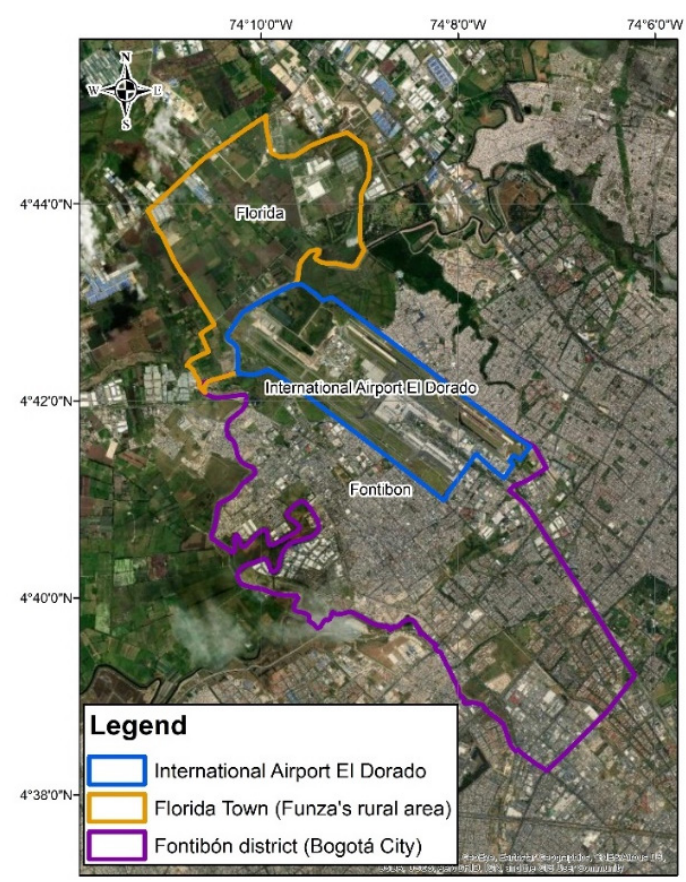

Figure 1: Fontibón District, Florida Town and International Airport El Dorado. 


\subsection{Characterization of environmental noise}

There were 62 sites monitored from 05-01-2019 to 07-31-2019 during the day (7:01 to 21:00) and night (21:01 to 7:00). In each sampling point (Fig. 2), the measurements were taken with a sound level meter, PCE - 428 class II (calibrated to $94 \mathrm{~dB}$ ), placed $4 \mathrm{~m}$ above the ground. Each measurement lasted 15 minutes, composed of five partial measurements.

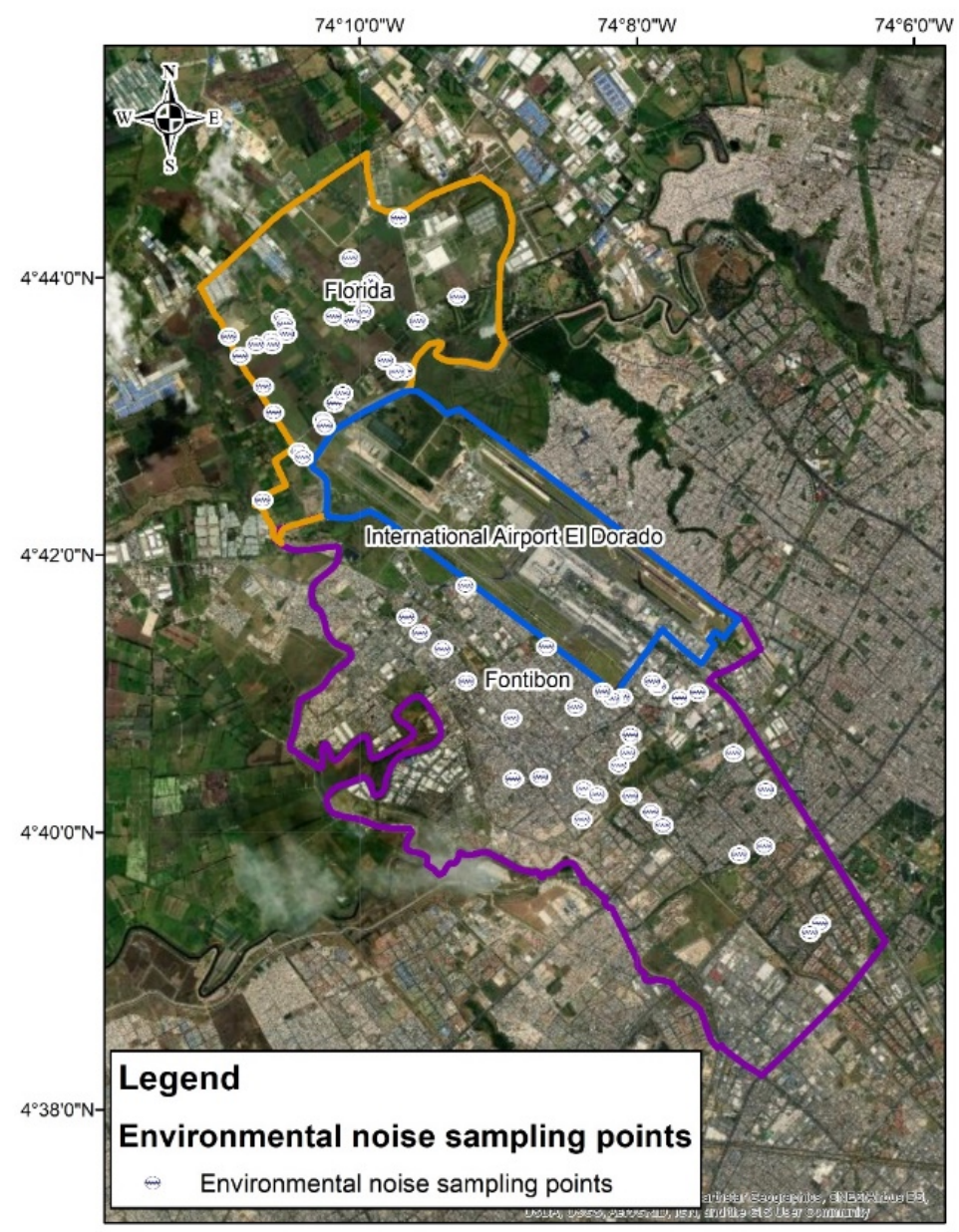

Figure 2: Location of the sampling points for environmental noise.

Each partial measurement corresponded to the direction of the microphone (North, South, East, West, and upwards), held for three minutes. During the measurements, the microphone was protected with a wind screen and was placed on a tripod. Additionally, the wind speed was measured with a Topker GM8908 anemometer, verifying that it did not exceed $3 \mathrm{~m} / \mathrm{s}$. The data were analyzed with Post-Processor SLM file - PCE 1.6, an acoustical measurement and analysis software developed based on ISO standard requirements. Finally, the data were classified according to the maximum allowed environmental noise levels $-\mathrm{dB}(\mathrm{A})$ (Table 1). 
Table 1: Maximum environmental noise levels allowed - dB (A). (Source: Ministry of Environment and Sustainable Development (Colombia), 2006 [7].)

\begin{tabular}{|c|c|c|c|}
\hline \multirow[t]{2}{*}{ Zone } & \multirow[t]{2}{*}{ Subzone } & \multicolumn{2}{|c|}{$\begin{array}{c}\text { Maximum allowed } \\
\text { environmental noise levels } \\
-\mathrm{dB}(\mathrm{A})\end{array}$} \\
\hline & & Day & Night \\
\hline $\begin{array}{l}\text { Zone A. Quietness } \\
\text { and silence }\end{array}$ & $\begin{array}{l}\text { Hospitals, libraries, day cares, nursing and } \\
\text { geriatric homes. }\end{array}$ & 55 & 45 \\
\hline \multirow{3}{*}{$\begin{array}{l}\text { Zone B. Quietness } \\
\text { and moderate noise }\end{array}$} & $\begin{array}{l}\text { Residential zones or exclusively intended for } \\
\text { housing, hotel and lodging development. }\end{array}$ & \multirow{3}{*}{65} & \multirow{3}{*}{50} \\
\hline & $\begin{array}{l}\text { Universities, primary and high schools, study } \\
\text { and research centers. }\end{array}$ & & \\
\hline & $\begin{array}{l}\text { Parks in urban zones other than outdoor } \\
\text { mechanical parks. }\end{array}$ & & \\
\hline \multirow{4}{*}{$\begin{array}{l}\text { Zone } \mathrm{C} \text {. } \\
\text { Intermediate } \\
\text { restricted noise }\end{array}$} & $\begin{array}{l}\text { Zones with permitted industrial uses, such as } \\
\text { industries in general, port areas, industrial } \\
\text { parks, free zones. }\end{array}$ & 75 & 70 \\
\hline & $\begin{array}{l}\text { Zones with permitted commercial uses, such } \\
\text { as shopping centers, stores, venues or } \\
\text { commercial facilities, automotive and } \\
\text { industrial mechanics workshops, sport and } \\
\text { recreational centers, gyms, restaurants, bars, } \\
\text { taverns, discos, bingos casinos. }\end{array}$ & 70 & 55 \\
\hline & $\begin{array}{l}\text { Zones with permitted offices use. Zones with } \\
\text { institutional use. }\end{array}$ & 65 & 50 \\
\hline & $\begin{array}{l}\text { Zones with other related uses such as } \\
\text { mechanical outdoor parks, zones for public } \\
\text { outdoor shows, streets, routes and highways. }\end{array}$ & 80 & 70 \\
\hline \multirow{3}{*}{$\begin{array}{l}\text { Zone D. Rural or } \\
\text { suburban zones of } \\
\text { quietness and } \\
\text { moderate noise }\end{array}$} & Residential suburban zone. & \multirow{3}{*}{55} & \multirow{3}{*}{45} \\
\hline & $\begin{array}{l}\text { Rural zone inhabited for agricultural } \\
\text { exploitation. }\end{array}$ & & \\
\hline & $\begin{array}{l}\text { Outdoor leisure and relaxation zones such as } \\
\text { national parks and natural reserves. }\end{array}$ & & \\
\hline
\end{tabular}

\subsection{Pittsburgh Sleep Quality Index, Colombian Version (PSQI-CV)}

The Pittsburgh sleep quality index, developed by Buysse and adapted for Colombia by the authors Escobar Córdoba and Eslava Schmalbach [8] and Buysse et al. [9], was applied. This scale is used to assess the quality of sleep and to distinguish people who sleep well from those who sleep poorly. This tool has been validated in various countries and translated into many languages. The questionnaire has 19 self-assessment questions and 5 questions directed at the roommate or bed partner, with only the first 14 used to obtain the overall score [10]. These questions are organized into 7 components: subjective sleep quality, latency, duration, efficiency, sleep disturbances, use of sleep medication, and daytime dysfunction. The sum of the scores of these components gives a total score that varies between 0 and 21 points, with a score of less than 5, called "No sleep problems", between 5 to 7 called "Needs medical attention", between 8 and 14 called "Needs medical attention and treatment" and 
over 15 or higher called "Serious sleep problem". Therefore, the higher the score, the lower the quality of sleep [10]. This tool has been used worldwide in similar studies [11], [12].

The size of the sample was calculated with eqn (1), based on the total population of Fontibón and the Florida District, for a total of 414 samples, which were geo-referenced

$$
\text { Sample Size }=\frac{\frac{z^{2} \times p(1-p)}{e^{2}}}{1+\left(\frac{z^{2} \times p(1-p)}{e^{2} n}\right)},
$$

$n=$ population size,

$e=$ error margin,

$z=z$-score, the number of standard deviations that a given proportion deviates from the mean.

\subsection{Noise mapping}

A noise map was generated with ArcGIS 10.5 based on the spatial distribution of the sampling points. Each sampling point had the following information: sound pressure levels and geographic coordinates. The sound pressure levels at night-time were interpolated with Inverse Distance Weighting (IDW) method, available within the Geostatistical Analyst tool of ArcGIS 10.5. IDW is a very popular technique in GIS; estimates are made from values at nearby locations, weighted only by distance from the interpolation site. This method is classified as a deterministic approach that interpolates the information available from sampling points to non-measured sections of the study area [13].

The output was classified according to the environmental regulation of Colombia (Table 1), grouping the classes every $5 \mathrm{~dB}(\mathrm{~A})$ and locating the PSQI-CV samples for observation of the relationship between sleep disturbance and environmental noise in the study area.

\section{RESULTS}

\subsection{Environmental noise levels}

During the daytime, $60 \%$ of the sampling points had sound pressure levels below the maximum allowed. Fig. 3 shows that, for the daytime, most of the points monitored in Fontibón complied; however, the same was not seen in the Florida town since most of the monitored points did not comply because the regulations are stricter for rural areas. During the night-time, the sound pressure levels had a significant change: only $18 \%$ of the sampling points complied with the maximum allowed levels. Fig. 3 shows that the points that complied were only in Fontibón; no monitored points in the Florida town complied. Furthermore, the sound pressure levels in the Florida town were modified by the landing and take-off activities of aircraft because they were the only source of noise emission evidenced in the study area during the field measurements.

\subsection{PSQI-CV}

Table 2 presents the results of the survey that was applied to determine the PSQI-CV in the Fontibón district and the Florida town. In both cases, the total average was greater than 5 , which, on the PSQI-CV scale, means that medical attention is required, as more clearly seen in Table 3, where it can be observed that $89 \%$ of the population surveyed in the Fontibón district and $60 \%$ in the Florida town needs medical attention. 
Therefore, it is likely that sleep disorders are linked to the impact of the environment (noise levels) of the El Dorado International Airport since the populations Fontibón and the Florida town are found in its area of influence.

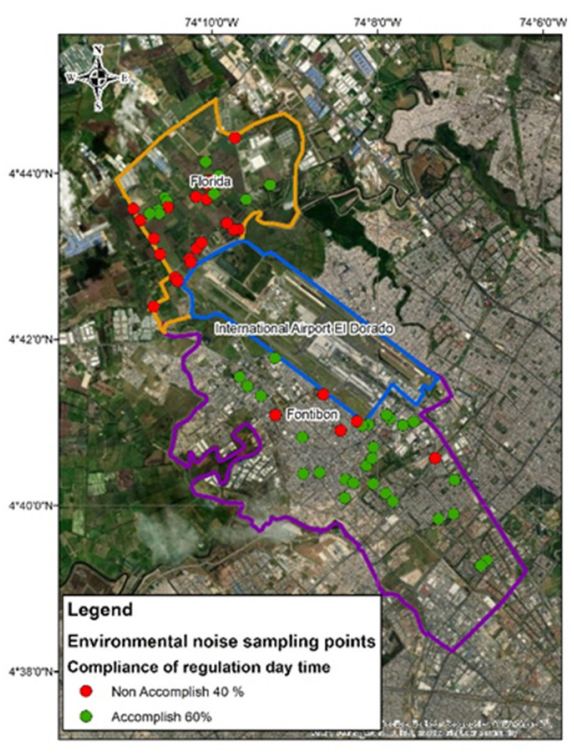

(a)

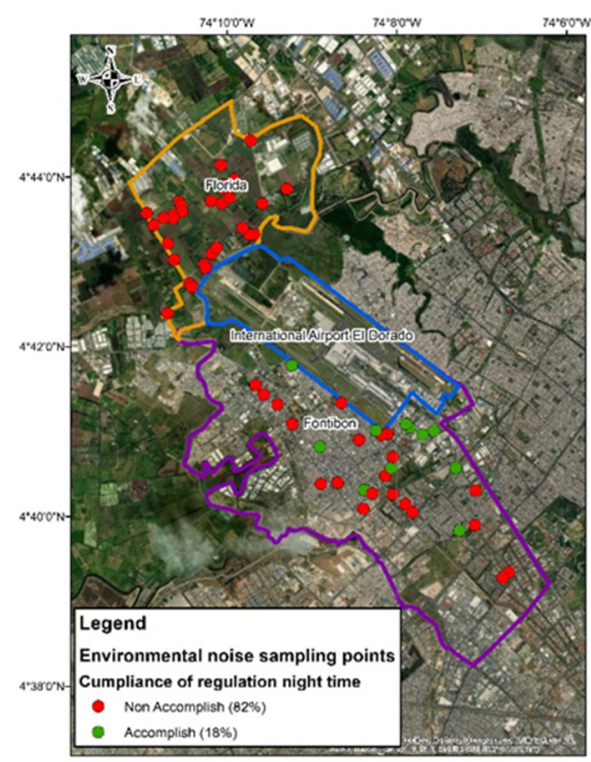

(b)

Figure 3: Environmental noise levels compliance. (a) Daytime; and (b) Night-time.

Table 2: PSQI-CV results.

\begin{tabular}{|l|c|c|c|c|}
\hline \multirow{2}{*}{ PSQI-CV component } & \multicolumn{2}{|c|}{ Fontibón $n=354$} & \multicolumn{2}{c|}{ Florida $n=60$} \\
\cline { 2 - 5 } & Mean & SD & Mean & SD \\
\hline 1. Sleep quality & 1.41 & 0.75 & 1.20 & 0.48 \\
\hline 2. Sleep latency & 1.19 & 0.81 & 1.34 & 0.98 \\
\hline 3. Sleep duration & 1.37 & 0.82 & 1.26 & 0.75 \\
\hline 4. Sleep efficiency & 1.37 & 0.82 & 0.75 & 0.96 \\
\hline 5. Sleep disturbance & 1.44 & 0.53 & 1.52 & 0.72 \\
\hline 6. Use of sleep medications & 0.31 & 0.65 & 0.13 & 0.78 \\
\hline 7. Daytime dysfunction & 1.50 & 0.89 & 0.77 & 1.24 \\
\hline PSQI Global score & 8.62 & 3.00 & 6.63 & 3.39 \\
\hline
\end{tabular}

Table 3: PSQI-CV sleep disturbance categorization.

\begin{tabular}{|l|c|c|}
\hline PSQI-CV sleep disturbances categorization & Fontibón $n=354$ & Florida $n=60$ \\
\hline$\leq 4$ "No sleep problems" & $7.9 \%$ & $40.00 \%$ \\
\hline $5-7$ "Needs medical attention" & $29.7 \%$ & $26.67 \%$ \\
\hline $8-14$ "Needs medical attention and medical treatment" & $59.6 \%$ & $30.00 \%$ \\
\hline$\geq 15$ "Serious sleep problem" & $2.8 \%$ & $3.33 \%$ \\
\hline
\end{tabular}




\subsection{Noise map versus sleep disturbance}

To correlate the noise monitoring and the application of PSQI-CV in the study area, an overlap of each sample was made on the noise map for night-time (Fig 4). It was evident that the modification in sleep quality was mostly seen in the areas where the sound pressure level exceeded 56 LAeq $\mathrm{dB}$, where people who needed medical attention or medical attention and treatment were located. However, there were two idiosyncrasies. First, there were respondents for whom PSQI-CV indicated that they do not have problems sleeping but who reside in areas where the sound pressure level was greater than or equal to $66 \mathrm{LAeq} \mathrm{dB}$. Second, on the other hand, there were respondents for whom ICSP indicated that they have serious sleeping problems but who reside in areas where the sound pressure level was less than or equal to 45 LAeq dB (Fig 4).

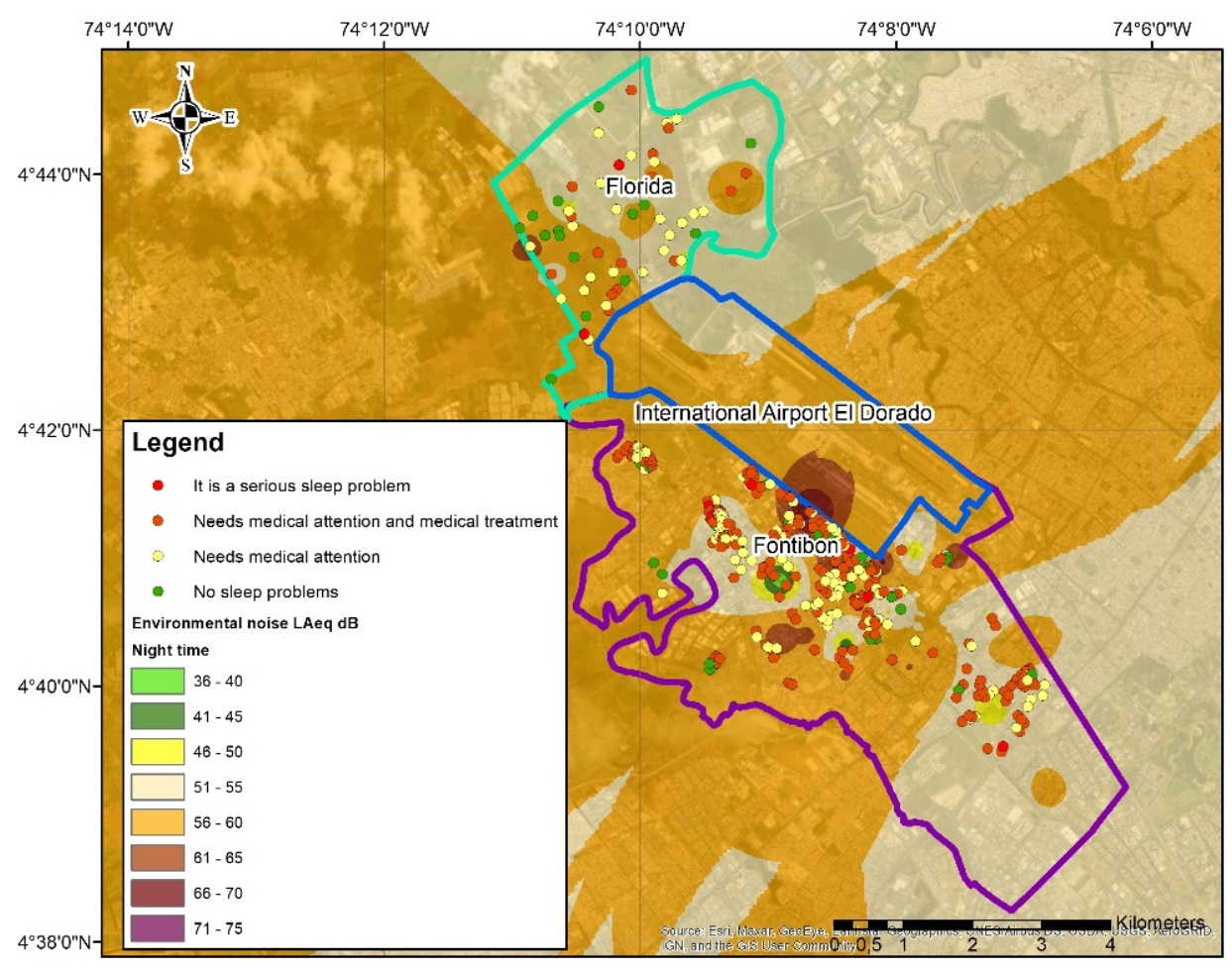

Figure 4: Night-time environmental noise map vs PSQI results.

Analysis showed that the respondents stated that the length of time they have lived in the study area has an impact; that is, the noise of the airport activities influences or does not influence the quality of the resident's sleep depending on whether the resident has lived in that area for 8 years or more. So, someone may currently have no problem sleeping according to PSQI-CV and live in an area with a very high sound pressure level, categorized as a good sleeper, because they have adapted to the conditions of the area. On the other hand, a respondent may have serious problems sleeping and live in a low sound pressure level area, requiring more time to fall asleep as the result of noise. 
Therefore, the respondents from the Florida town, an area with sound pressure levels greater than or equal to $56 \mathrm{LAeq} \mathrm{dB}$, did not present sleep disturbances because this impacted population has adapted over time and the perception of noise does not interfere with their PSQI-CV.

\subsection{Land use planning}

Land use planning actions to reduce airport noise impacts are: land acquisition, relocation and acoustic isolation. In this case, relocation is seen as a mayor challenge that could solve the sleep quality in nearby communities. El Dorado II International Airport is currently in the planning phase, which aims to expand the operation of El Dorado, since it is working at full capacity. Therefore, it is recommended to evaluate the possibility that the new airport will not only expand the operation, but also relocate the entire airport.

\section{CONCLUSIONS}

The present study evidenced high levels of night noise and poor sleep quality in the town of Fontibón in the city of Bogotá and in the Florida District in the rural area of Funza. Although other sources of noise emission, such as vehicular traffic, are evident in Fontibón, in the Florida District, it was observed during field measurements that the only source of noise was the sound of planes landing at the El Dorado International Airport.

These results confirm that the strategies that are currently being implemented by the El Dorado International Airport are not correcting or mitigating the environmental impact that airport activities are causing on the levels of environmental noise in nearby towns. This was evidenced in this study by the strong relationship between non-compliance with regulations for night-time environmental noise levels and poor sleep quality in the communities.

It is necessary from land use planning relocate El Dorado International Airport entire operation to a new area.

\section{ACKNOWLEDGEMENT}

The authors thanks to Seruans Environment S.A.S for providing the equipment for environmental noise measurements.

\section{REFERENCES}

[1] Fyhri, A. \& Aasvang, G.M., Noise, sleep and poor health: Modeling the relationship between road traffic noise and cardiovascular problems. Science of the Total Environment, 408(21), pp. 4935-4942, 2010.

[2] Tezel, M.N., Sari, D., Erdol, M., Hamamci, S.F. \& Ozkurt, N., Evaluation of some health impact indices in two airports' domain. Applied Acoustics, 149, pp. 99-107, 2019.

[3] Barrera, S., El Ruido Aeronáutico: Realidad que Enfrenta el Aeropuerto el Dorado y sus Comunidades Aledañas, p. 40, 2014.

[4] Unidad Administrativa Especial de Aeronáutica Civil, El Dorado II permitirá atender la futura demanda de viajeros del país. Bogotá D.C., 2016.

[5] Moreno-Martínez, 1., Planeación del Suelo en Torno al Aeropuerto. Consideraciones para un Ordenamiento Territorial Compatible, Universidad Nacional de Colombia, 2019.

[6] Arantes, B., Santos, G.S. \& Gomes, R.D.A., Land use policy in the vicinity of airports: Analysis and lessons learned from the Brazilian situation. Land Use Policy, 90(November), p. 104314, 2020. 
[7] Ministerio de Ambiente y Desarrollo Sostenible, Resolución 627 de 2006, 2006.

[8] Escobar Córdoba, F. \& Eslava Schmalbach, J., Validación colombiana del índice de calidad de sueño de Pittsburgh. Revue Neurologique, 40(3), p. 150, 2005.

[9] Buysse, D.J., Reynolds, C.F., Monk, T.H., Berman, S.R. \& Kupfer, D.J., The Pittsburgh sleep quality index: A new instrument for psychiatric practice and research. Psychiatry Research, 28, pp. 193-213, 1988.

[10] Saavedra, J. et al., Estudio epidemiológico de salud mental en Lima metropolitana Y Callao - Replicación 2012. Anales de Salud Mental, 29, p. 269, 2013.

[11] Kim, S.J. et al., Exposure-response relationship between aircraft noise and sleep quality: A community-based cross-sectional study. Osong Public Health and Research Perspectives, 5(2), pp. 108-114, 2014.

[12] Luna-Solís, Y., Robles-Arana, Y. \& Agüero-Palacios, Y., Validación del Índice de Calidad de Sueño de Pittsburgh en una muestra peruana. Anales de Salud Mental, 31(2), pp. 23-30, 2015.

[13] Bajjali, W., ArcGIS for Environmental and Water Issues, Springer International Publishing AG, 2018. 